\title{
THE USE OF CLUSTERING TECHNIQUE FOR IMPROVING WRITING DESCRIPTION TEXT OF THE THIRD SEMESTER STUDENTS OF UNINDRA
}

\author{
Wiwik Yully Widyawati \\ Email: Wiwik121@gmail.com
}

\begin{abstract}
Pendidikan Bahasa Inggris, Fakultas Bahasa dan Seni, Universitas Indraprasta PGRI
\end{abstract}

\begin{abstract}
The purpose of the study is To find out the clustering technique is effective or not in improving students' ability in generating ideas for writing description text of the third semester of the English Department of UNINDRA in the academic year of 2017/2018". Target in this research is scholar of university. The sample of this research is thirty students. This research uses book and test as the source of data. In this case, test used in this research is writing test about writing description text. This research uses a quantitative metho, experiment.. The findings of this research are by analyzing the students' test about writing description text. After analyzing data, the result of the test applied to the students by using clustering technique showed that the highest score was 88 , the lowest was 65 . The mean score was 78.3 . If it is consulted to the grade classification of writing, the mean achievement belongs to good grade, while for control group or by using conventional technique, the highest score was 70 and the lowest score was 35. The mean score was 52.8. If it is consulted to the grade classification of writing, the mean achievement belongs to poor grade. Based on the statement above, it can be concluded that the result of research said that there is good effect clustering technique in improving the third students' ability in writing description text. So, the technique clustering is effective for improving writing ability.
\end{abstract}

keywords: technique of learning, clustering technique, writing skill and descriptive texts.

\section{Abstrak}

Penelitian ini bertujuan untuk untuk mengetahui apakah teknik clustering efektif atau tidak dalam meningkatkan hasil tulisan descriptive teks mahasiswa semester 3 Unindra. Subjek dalam penelitian ini adalah mahasiswa. Sampel yang digunakan dalam penelitian ini adalah 30. Penelitian ini menggunakan buku dan tes sebagai sumber data. Dalam hal ini test yang digunakan dalam penelitian ini adalah tes menulis deskripsi teks. Penelitian ini menggunakan metode quantitative yaitu experiment. Temuan penelitian ini adalah melalui analisis test yang dilakukan mahasiswa tentang menulis deskripsi teks. Setelah menganalisis data, hasil dari test yang diterapkan kepada mahasiswa yang menggunakan teknik clustering menunjukkan bahwa nilai tertinggi adalah 88, nilai terendah adalah 65 . daripada mahasiswa yang diterapkan menggunakan konvensional teknik. Nilai Rata -ratanya yaitu 78.3. jika dikonsultasikan ke klasifikasi tingkatan nilai menulis, rata-rata kemampuan menulis dikategorikan bagus. Sebaliknya, hasil dari test yang diterapkan kepada mahasiswa yang menggunakan teknik konvensional atau kelas control, menunjukkan bahwa nilai tertinggi adalah 70, nilai terendah adalah 35. daripada mahasiswa yang diterapkan menggunakan konvensional teknik. Nilai Rata -ratanya yaitu 52.8. jika dikonsultasikan ke klasifikasi tingkatan nilai menulis, rata-rata kemampuan menulis dikategorikan buruk. Berdasarkan pernyataan diatas, hal ini dapat disimpulkan bahwa hasil penelitian menyatakan bahwa ada pengaruh yang bagus mengenai penggunaan teknik clustering dalam meningkatkan kemampuan menulis descriptive teks. Jadi, teknik clustering sangat efektif dalam meningkatkan kemampuan menulis.

kata kunci : Teknik pembelajaran, clustering teknik, menulis dan teks descriptive

\section{INTRODUCTION}

Basically, Learning English as a foreign language is important. In Indonesia government, English is considered as a first foreign language Learning. English is one of a subject which is learnt the students in Indonesia. One of the aims of teaching English is developing the ability to communicate. English is consisting of four skills that should be learnt, they are listening, speaking, reading and writing. Although the actional competences consist of listening, speaking, reading and writing but the writer is mainly focused on writing skill. ,because writing is considered the most difficult and complicated language skill to be learned. Writing needs hard thinking to produce idea, words, sentences, paragraph, and composition. 
Writing is one of the important skills to be mastered by the students. They use it to communicate to each other, as means of ideas and emotional expression, because when they write their ideas and emotion creatively, they are communicating on paper in their very best way and purposes. Meyers (2005:1) states that:

"Writing is a way to produce language, which you do naturally when you speak. Writing isn't much different, except that you take more time to think about your subject, the person or people you'll be discussing it with, and the goal you hope to achieve in that discussion. And you also take more time to revise your work". That explanation shows that when we write, it meant that we make conversation or dialogue by self in our daily life.

In having good writing, the students have to know some of the rules in writing. They are such as using correct vocabulary, grammar, and spelling. One of the ways in solving this problem, as what is suggested by popular writers is to keep on practicing to write. One of them is stated by Bram (2002: 7), "it is true that we improve our writing mainly through writing itself." By encouraging and adjusting the students to write something. Automatically, they are also accustomed to select the appropriate words, to construct the correct grammar, and to spell words correctly.

Writing is considered as the difficult and complicated skill for the students because when they want to write paragraph, they should know and learn about several elements of writing such as grammar, vocabulary, and spelling.
Considering with those elements of writing, many students in all levels have poor writing habits, especially at college level. Therefore, Based on the observation, the researcher has obtained the data through observation almost all of the third semester students of Unindra got any difficulties in learning English especially in writing simple paragraphs.

Generally, they did not know how to develop their idea that they wanted to write. They did not master the use of grammatical sentences well. Beside that, the students had problem with grammar. As a result, the idea of a paragraph cannot be communicated well without having a good grammar. To have a good writing, they have to know how to write words correctly. After knowing the way how to write words correctly, the students will not make similar mistake in their spelling and the readers can get the meaning of the word itself. Another problem which was faced by the students was lack of vocabulary. It was one of the crucial things that they could not master well. Considering those problems, the researcher was interested in conducting her research in this class focused on writing simple descriptive paragraphs. Based on that condition, the researcher applied better technique in order that the students mistakes in writing could be minimized. Therefore, the students will not make similar mistakes in their writing. To overcome this problem, a technique which can improve the students' English writing is needed

One of the techniques is clustering. Clustering is a kind of technique which can be used in prewriting stage. It is introduced by 
Gabriele Lusser Rico, a professor of English and Creativity at San Jose State University, California in 1980s. It is a technique which provides an alternative way for writers to do the brainstorming before starting to write. Rico also claims that clustering is a kind of technique in brainstorming which benefits greatly from the right brain (which she called „Design mind ${ }^{\text {ee }}$ ), the part of the brain in which non-linear pattern and images production occur (Folit, 2009:68). Likewise, Pica (1986, as cited by Baroudy, 2008) defines clustering as a "non-linear brainstorming process that generates ideas, images, and feelings around a stimulus word until a pattern becomes discernible".

Doing clustering involves several simple steps which can be easily accomplished. First, it is started by writing down a word or phrase in the center of a blank sheet and circling it. Next, it continues by immediately writing down related words or phrases which come into mind, circling each of them, and making line which connects each to the main, initial circle or "bubble just like "spokes in a wheel" (Baroudy, 2008:105).Finally, writers may stop after the given time has passed, then they can examine the cluster to pick the subtopics that interest them most or are considered to be covered by their competence. Overall, the words or phrases in the cluster provide a starting point for writers to see and understand their world from a new perspective (Folit, 2009:56).

Previous research was conducted by Ferra Puspito (2013) entitled the influence of clustering technique toward writing skill to the third class of hearing impairment student in SDLB-B Karya Mulia 1 Surabaya", a thesis . Surabaya State University. He aimed to know whether there was application influence of clustering technique toward writing skill to the third class of hearing impairment student in SDLB-B Karya Mulia 1 Surabaya. This research was done by using quantitative approach, preexperimental design, ang one group pre-test post test design. The result showed that there was enhancement score of writing basic sentence skill. There was significant influence using clustering technique toward writing skill to the third class of hearing impairment student in SDLB-B Karya Mulia 1 Surabaya.

Afrilia Suheni (2011) also did the research entitled "The Use of Clustering Technique to Improve Students' Ability in Writing Analytical Expositions for Senior High School" (An Experimental Research at the Students of the State Senior High School 1 Weru Sukoharjo of the Eleventh Year in the academic year 2010/2011). The purpose of this study is to find how effective clustering techniques can improve the students' ability in writing analytical expositions. She used questionnaire and test to support the data. The result was shown by differences of student mark and the average of the scores in every test. The average of the pretest was 54.4 and the post-test was 79.6. It can be inferred that the clustering technique was effective helping students to generate ideas in writing analytical texts.

From what has been presented above, it is clear that clustering technique is important to implement in the teaching learning. This technique also has many 
advantages. Therefore, the situations above have led the researcher's interests to investigate whether the clustering technique is effective or not in improving students' ability in generating ideas for writing description text.

\section{LITERATURE REVIEW}

\section{Description text}

Descriptive is what readers need to see in order to image the person, things and place, etc. Description requires recording a series of detailed real observation. The success of a description lies in the difference between what a reader can image and what a writer actually saw and recorded According to Gerot and Wignel (2002: 208) "Description is texts that function to describe a particular person, place or things". The Generic structure of description text is divided into two elements according to Mark and catty (2010:50). They are: Identification: identifies phenomenon to be described, (b) Description : describes parts, qualities, characteristics. There are four significant lexicogrammatical features to support Descriptive text, they are: (a) Focus on Specific Participant, (b) Use of Attributive and Identifying Processes, (c) Frequent use of Epithets and Classifiers in nominal groups, (d) Use of Simple Present Tense

\section{Clustering Technique}

Technique is method of doing something expertly or needs skill (Richard, 2001:6). In addition, a technique is implementation that which actually takes place in a classroom. Referring to the idea above, clustering is one of techniques in teaching writing

138 | Jurnal Kredo

Vol. 1 No. 2 April 2018 because it is a teacher's strategy which is applied in the classroom.

When people want to write, the first thinking in her mind is to find out what they know about a topic. The first stage of writing process is prewriting. Prewriting can helps to generate a topic. One of strategies which can be used in teaching writing in the classroom is clustering technique.

Cooper and Axelrod (2005: 389) viewed that clustering is an invention activity which reveals possible relations among facts and ideas. It means that clustering is a creative activity, because when creating a clustering people tries to find things related to the topic. Clustering requires a brief period of initial planning. Based on that definition, clustering is activity before writing a text by making a note in advance about the ideas that are owned and relevance of the fact that the text will be written.

Clustering is another effective method you could use to narrow a subject. As Langan said that clustering also known as diagramming or mapping, is another strategy that can be used to generate material for a paper. This method is helpful for people to think in a visual way. In addition clustering is another strategy that can be used to generate material for a paper.

According to Mattix (2003:26) Clustering is uncensored brainstorming combined with doodling. Clustering produces an overview of a subject, suggests specific topics, and yields related details. The writer summarizes that clustering is making a visual map or new associations that allows thinking more creatively and to begin without 
clear ideas. Clustering can be useful for any kind of writing.

\section{The Step of Using Clustering}

Clustering can be useful for any kind of writing. Writers use it in the early stages of planning an essay in order to find subtopics in a topic or to organize information. They may try and discard several clusters before finding one that is promising. Clustering works as follows (Cooper:2005,p461)

1. In a word or phrase, write your topic in the center of a piece of paper. Circle it.

2. Also in a word or phrase, write down the main parts or central ideas of your topic. Circle these, and connect them to the topic in the center.

3. The next step is to

4. Generate facts, details, examples, or ideas related in any way to these main parts of the topic. Cluster these around the main parts.

\section{Teaching Writing Using Clustering} Technique

The followings are steps in teaching writing using clustering technique( Cooper, 2005:462):

1. Step 1: Introduce the concept of clustering technique to students.

2. Tell them that clustering technique would help them in generate ideas when they started to write.

3. Step 2: Leading students to generate ideas in form clustering technique on the whiteboard as a model. Put the topic in the center by using box or other shapes to make it more interesting, and put keywords related to the topic by using lines or arrows. Students don't have to worry in generating ideas; it is free for them to organize their ideas as long as related to the topic given.

4. Step 3: Ask students to write the first draft based on the design of clustering technique samples that have been made on the whiteboard to know that students have easy when started to write by using clustering technique.

5. Step 4: After students are able to use clustering technique, ask them through selected topic to make a procedural recount text referred to their own experience. Give students an evaluation to check their ability in writing and to know their problems in writing.

\section{RESEARCH METHODOLOGY}

\section{Research Design}

In this research, the writer uses quantitative method. Research method in this study is experimental research. The experiment is the most powerful quantitative research method for establishing cause-andeffect relationship between two or more variables. Therefore, experimental findings about effectiveness of educational practices sometimes have an impact on the opinions and decisions of policy makers, educators, and other groups (Gall, 2003:366)

In this study, the writer used a quantitative approach. It is used to identify numerical differences between control group and experiment group.

\section{Population and Sample}

In conducting the research the writer needs the source of data for observing, those are; population and sample. In this research study, the population that the writer uses in this study is the students of third 
semester in Unindra PGRI, academic year of 2017/2018. They have ten classes in of third semester. In other hand, the total population of this study is about 400 students. From ten classes of students the third semester in Unindra, the writer just only picks one to class become the sampling of the study. On the average, each class almost has the same number of students about 30 students for experiment and control class. By using random sample, the writer gets class of $3 \mathrm{H}$ and $3 \mathrm{I}$ being the research study.

\section{Research Variables}

Kerlinger as cited by Arikunto (2003:102) states that: "All experiments have one fundamental idea behind them: to test effect of one or more independent variables on a dependent variable (it is possible to have more than one dependent variable in an experiment)".

In the simplest terms, a variable is something that may vary, or differ. F $r$ instance, a person's proficiency in Spanish as a foreign language may differ over time as the person learns more and more Spanish (Brown, 2005:7).

A variable is a quantitative expression of a construct. Variables usually are measured in terms of scores on an instrument such as an achievement test or an attitude scale or in terms of categories of a construct (Gall, 2003:167).

There are two variables in this experimental activity. They are: (1) the independent variable is the methods of teaching writing for the object; here I use the clustering technique in teaching description text. (2) the dependent variable of this study is the students'

\section{0 | Jurnal Kredo}

Vol. 1 No. 2 April 2018 achievement manifested in the test score.

\section{Technique of Collecting Data}

In this study, the writer took the data through library activity, observation and and test.

\section{Procedure of Collecting Data}

To get truth worthiness, the researcher uses the technique of triangulation. Triangulation is a combination of data collection. It contains of observation, interview, documentation, and field notes (Arikunto : 2016:87).

The researcher would combine the result data from test, field note, observations, and procedure of data collection are: a).The researcher observed the class in the third semester and makes field notes. From the field notes, the researcher drew data intended. b). the researcher conducted the real experiment. c). giving test to the students. After that, the result of the test was collected and then identified the mistake of the result writing by using clustering's technique and conducting the statistical analysis of the test.

\section{Instrument}

Kerlinger (2003: 48) states that instrument is an important device for collecting the data in a research study. He also states that for most research, the instrument used to measure the achievement in education is a test. Harris (2000: 71) "there are two basic kinds of test instrument used to measure the four languages skills of the students, i.e. the objectives test and essay test". The instrument which is used in this research is essay test. To collect the data needed in this research, the 
writer used rating scale from the pre test and post test. Some of the data are gained from the pre test and post test that was conducted at the beginning and the end of the experiment.

In conducting the research, before giving the treatment, the writer conducted a pre test for the two classes, control and experimental groups. It was conducted on writing test. In this test, the writer asked the students to write descriptive text. This test has a purpose to find out the initial ability of both groups, either experimental and control group. On the other hand, the post test was conducted to measure the students' ability in writing descriptive texts after treatment. The test contains the same criteria in writing descriptive texts as in the pre test. Besides, it was given to the same experimental and control groups.

\section{Quality of the Test}

Whenever a test or other measuring device is used as part of the data collection process, the validity and reliability of that test is important. After that, the writer also tests the difficulty of an items and discriminating power.

\section{Procedure of Experiment}

Conducting an experiment always requires some steps, which have to be done in a chronological order. I will take the following steps as I will work on my experiment. The procedure of experiment will be conducted as follows: Choosing the two classes of the research, Taking two groups consisting of forty students, in making 30 each group, Conducting the real experiment.

\section{Techniques of Analyzing the Data}

In this research, I used one of method of data analysis is statistical analysis using ANOVA. After collecting data through writing test, the data are the percentage description. The test scores showed the student's ability in writing Descriptive Texts through clustering technique. In giving the score to students' writings, I used the scoring guidance rubric taken from my own' categories which included Grammar, vocabulary and relevance because it can easy the student to assess the result of writing descriptive texts.

The process is:

Giving the score test.

Getting the mean

After getting the result of the test, the writer will measure each aspect of writing used the following formula:

$$
\mathrm{P}=\frac{L}{N} \times 100 \%
$$

After collecting data, the writer analyzes the result of students writing by using clustering technique. The formula of mean as follows:

$$
\bar{X}=\frac{\sum x}{N}
$$

(Sudjana, 2002: 67)

In giving the score, the writer used rubric of scoring suggested by Harris (2000:134)

\section{RESEARCH RESULT AND FINDINGS}

After doing the test, the result of the test was analyzed. Then, the writer look for: first, the data of scoring writing description text for experiment group and control group; second,validity and realidity; third, discriminating power and difficulty level. 


\section{Description of Data}

a) The data of writing ability for experiment class

To know the scoring of the students' writing ability, they are given writing test for 30 students R3I. Based on the data, it can be made distribution frequency of table for experiment group about the the students' writing ability :

\section{Table 1}

The distribution frequency of the students' writing ability for experiment group

\begin{tabular}{|c|c|c|c|c|c|}
\hline Score & $\mathbf{f}_{\mathbf{i}}$ & $\mathbf{x}_{\mathbf{i}}$ & $\mathbf{x}_{\mathbf{i}}{ }^{\mathbf{2}}$ & $\mathbf{f}_{\mathbf{i}} \cdot \mathbf{x}_{\mathbf{i}}$ & $\mathbf{F}_{\mathbf{i}} \cdot \mathbf{x}_{\mathbf{i}}{ }^{2}$ \\
\hline $65-68$ & 2 & 66,5 & 4422,25 & 133 & 8844,5 \\
\hline $69-72$ & 3 & 70,5 & 4970,25 & 211,5 & 14910,75 \\
\hline $73-76$ & 7 & 74,5 & 5550,25 & 521,5 & 38851,75 \\
\hline $77-80$ & 6 & 78,5 & 6162,25 & 471 & 36973,5 \\
\hline $81-84$ & 6 & 82,5 & 6806,25 & 495 & 40837,5 \\
\hline $85-88$ & 6 & 86,5 & 7482,25 & 519 & 44893,5 \\
\hline & 30 & & & 2351 & 185311,5 \\
\hline
\end{tabular}

After that, the distribution of frequency above can be seen in the following histogram picture:

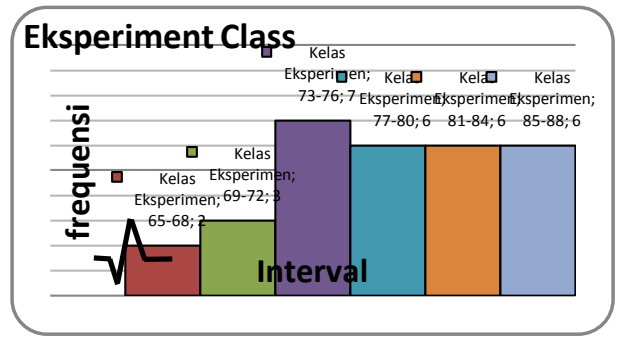

Picture 1

Histogram of the writing ability for experiment class

If it is seen from the result of counting and diagram above, it can be said that the Mean $(X)=78,3$, median $(\mathrm{Me})=78,5$, modus $(\mathrm{Mo})=$ 75,7 , Standar Devitiation $(S)=6$ dan varians $\left(S^{2}\right)=36,9$. So, the students' ability in writing description text for experiment class by using clustering technique are good.

b) The data of writing ability for control group

To know the scoring of the students' writing ability, they are

142 | Jurnal Kredo

Vol. 1 No. 2 April 2018 given writing test for 30 students $\mathrm{R} 3 \mathrm{H}$. Based on the data, it can be made a table of distribution frequency for control class in writing ability'

students as follow:

Table 2

Distribution frequency for control class in

\begin{tabular}{|c|c|c|c|c|c|}
\hline Score & $\mathbf{f}_{\mathbf{i}}$ & $\mathbf{x}_{\mathbf{i}}$ & $\mathbf{x}_{\mathbf{i}}^{\mathbf{2}}$ & $\mathbf{f}_{\mathbf{i}} \cdot \mathbf{x}_{\mathbf{i}}$ & $\mathbf{F}_{\mathbf{i}} \cdot \mathbf{x}_{\mathbf{i}}{ }^{\mathbf{2}}$ \\
\hline $35-40$ & 3 & 40,5 & 1640,25 & 121,5 & 4920,75 \\
\hline $41-46$ & 2 & 43,5 & 1892,25 & 87 & 3784,5 \\
\hline $47-52$ & 10 & 49,5 & 2450,25 & 495 & 24502,5 \\
\hline $53-58$ & 9 & 55,5 & 3080,25 & 499,5 & 27722,25 \\
\hline $59-64$ & 4 & 61,5 & 3782,25 & 246 & 15129 \\
\hline $65-70$ & 2 & 67,5 & 4556,25 & 135 & 9112,5 \\
\hline Sum & 30 & $\mathbf{3 1 8}$ & & $\mathbf{1 5 8 4}$ & $\mathbf{8 5 1 7 1 , 5}$ \\
\hline \multicolumn{6}{|c|}{ writing ability' students } \\
\hline
\end{tabular}

After that, the distribution of frequency above can be seen in the following histogram picture:

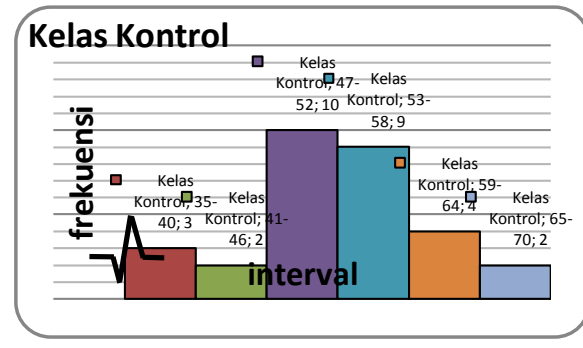

Picture 2

Histogram of the writing ability for Control class

If it is seen from the result of counting and diagram above, it can be said that the Mean $(X)=52.8$, median $(\mathrm{Me})=52.5$, modus $(\mathrm{Mo})=$ 51.8, Standar Devitiation $(S)=7.27$, dan varians $\left(S^{2}\right)=52.9$. So, the students' ability in writing description text for experiment class by using clustering technique are poor.

\section{The Testing of Requirement Analysis \\ Normality \\ Test}


The normality test result could be seen from "Liliefors or "Kolmogorov Smirnov", by computation using SPSS for window release 15, if it is gotten $P$ value > 0.05 or the computation $L<L$ table, it can be concluded that the distribution data was normal. More details normality test results can be seen in the table in the appendixes .

If $\mathrm{n}=30$ and the real level( taraf nyata) $0.05, \quad \mathrm{~L}_{\text {table }}=0,161$. $\mathrm{L}_{\text {value(hitung) }}=0,110$. The result showed $\mathrm{L}_{\text {value(hitung) }}<\mathrm{L}_{\text {tabel }}$ or $0.110<0.161$, it can accept $\mathrm{H}_{\mathrm{O}}$. So, it can be concluded that the data of experiment class has population that have normal distribution.

\section{The testing of Normality for Control Class}

The table of value (table hitung) liliofers for control class can be seen in the appendixes table 4 .

If $\mathrm{n}=30$ and the real level( taraf nyata) $0.05, \quad \mathrm{~L}_{\text {table }}=0,161$. $\mathrm{L}_{\text {value(hitung) }}=0.1517$. The result showed $\mathrm{L}_{\text {value(hitung) }}<\mathrm{L}_{\text {tabel }}$ or $0.1517<0.161$, it can accept $\mathrm{H}_{\mathrm{O}}$. So, it can be concluded that the data of control class has population that have normal distribution.

\section{Testing of Homogeneity}

Testing of homogeneity between experiment group and control group are done by using testing of Fisher (uji fisher). if $\mathrm{F}_{\text {hitung }}<\mathrm{F}_{\text {tabel }}$, it meant that homogeneity. On the contrary, if $F_{\text {hitung }}>F_{\text {tabel }}$ it meant that not homogeneity. Moreover, $\mathrm{F}_{\text {tabel }}=1.85$ and it can be concluded that : $\mathbf{F}_{\text {hitung }} 1.43<\mathbf{F}_{\text {tabel }} 1.85$, it meant that it is homogeny.

\section{Test of Research Hypothesis}

From the distribution table $\mathrm{t}$ for $\alpha=0,05$ and $\mathrm{dk}=n_{1}+n_{2}-2=58$, it is not found directly.So, the value $\mathrm{t}_{\text {tabel }}$ for $\alpha=0,05$ and $\mathrm{dk}=58$ is $\mathrm{t}_{\text {tabel }}$ $=1,67$. Because of $t_{\text {hitung }}>t_{\text {tabel }}$ or $15,17>1,67$ it meant that $\mathrm{H}_{0}$ refusing. It meant that on the level of confident $95 \%$, the mean of the students writing ability who are given the clustering technique are same with the student using conventional technique.

\section{Discussion of the Research Result}

In this research, it can be gotten that the result of data the students' ability in writing description texts using clustering technique and conventional technique are 1) the mean of score the students' ability in writing description text for experiment class which is implemented clustering technique is higher than control class which is implemented conventional technique. It proved that the students' ability in writing description text which use clustering technique is better than using conventional technique. 2) from the result of testing statistic hypothesis, it is gotten the data of value $t_{\text {hitung }}=15.17>t_{\text {table }}=1.67$. it meant that the result showed that $\mathrm{H}_{1}$ is accepted and $\mathrm{H}_{0}$ is refused or not accepted. Therefore, it is proved that when the students are taught using clustering technique in writing process, they can easy organize many ideas.

Moreover, it can be concluded that the implementation clustering technique can improve and effective way on writing ability of third semester students Unindra.

\section{Findings}

From previous explanations above, below is the description of the test writing ability applied to students by clustering technique and 
conventional technique. The result of the test applied to the students by using clustering technique showed that the highest score was 88, the lowest was 65 . The mean score was 78.3. If it is consulted to the grade classification of writing, the mean achievement belongs to good grade, while for control group or by using conventional technique, the highest score was 70 and the lowest score was 35 . The mean score was 52.8. If it is consulted to the grade classification of writing, the mean achievement belongs to poor grade.

Based on the explanation above, it was found that clustering technique was an appropriate technique applied in writing descriptive texts. First, the writer ought to concern to explain about clustering technique to the students. It was done because students were not acquaintance this technique which was considered as a new technique. Consequently, the students were supposed to understand and could apply this technique well. Once, the students were enthusiastic knowing that they would have different activity as usual. Actively they asked about the technique and paid attention to the writer's explanation. For a while, the students got confused and bored about clustering technique, but the writer encouraged the students to take it easy about the technique while explained more detail about clustering technique so that the students understood. After all, the writer checked the students' understanding about technique and made sure that all was fine.

Second, the writer provided the instrument used in this activity such as paper that had been fulfilled the writing descriptive texts. After all had been done, the teacher explained to the students about what the students should do with that paper on them.

Third, the implementation of clustering technique would be held in the classroom.

The result of the data analysis showed that the use of clustering technique gave effect for improving the students' writing descriptive texts seemed to be applicable for third semester students of Unindra. Technique helped the students to solve the problem in writing descriptive texts and they can find and organize many ideas. In addition, the students were more motivated, active in the learning activity, got better understanding and had better achievement.

In applying clustering technique, it was found some advantages and disadvantages. The advantages were the students can improve their skill especially in vocabulary. It was caused by clustering technique, they find many kinds of word or vocabulary. On the other hand, the disadvantage was it took long time for thinking. So, when there is writing lesson, the teacher should take and use time appropriately or choose the schedule which long time.

From the conclusion above, clustering technique had given effect to the student writing descriptive text. It can be proven from the students' score. Through this technique, the students can develop and improve their skill either in writing, grammar or vocabulary. They also can increase their motivation to write because they don't afraid to make mistake in grammar and vocabulary. 


\section{CONCLUSION}

The problems in this research are:" is the clustering technique effective in improving students' ability in generating ideas for writing description text of the third semester of the English Department of UNINDRA in the academic year of 2017/2018?". This research answers the questions by analyzing the result of the test about writing description text.

The writer concludes that Learning English as a foreign language in university is very important. In this globalization era, the students of university must understand and can write correctly, unity and their writing have value and long. Therefore, they have to be given motivation and the good techniques and methods in order they have high motivation to write and love writing. They also do not think that writing is difficult skill. However, they think that writing enjoyable and easiest activity. That is why the writer has tried to find out is the clustering technique effective in improving students' ability in generating ideas for writing description text of the third semester of the English Department of UNINDRA in the academic year of 2017/2018.

In the first page, the writer has mentioned, the purpose of this research is to find out is the clustering technique effective in improving students' ability in generating ideas for writing description text of the third semester of the English Department of UNINDRA in the academic year of 2017/2018?. Based on the data analysis, the writer has concluded that: The result of the test applied to the students by using clustering technique showed that the highest score was 88 , the lowest was 65 . The mean score was 78.3 . If it is consulted to the grade classification of writing, the mean achievement belongs to good grade, while for control group or by using conventional technique, the highest score was 70 and the lowest score was 35 . The mean score was 52.8 . If it is consulted to the grade classification of writing, the mean achievement belongs to poor grade.

It also has compared between the result of score control class and experiment class from determining mean, median, modus and standars deviation. Beside that, to analyse the data which have gotten the writer in this research, it is tested, normality test by using testing of liliefors and the result for experiment group is $\mathrm{L}_{0} 0.110$ and the value of table with $\mathrm{n}$ $=30$ dan real level 0.05 so it is gotten $\mathrm{L}_{\text {tabel }}=0.161$ because $\mathrm{L}_{0}<$ $\mathrm{L}_{\text {tabel, }}$ so the result of data score in the experiment class have contribution normal. On the contrary, the result of test in the control class $\mathrm{L}_{0}=0.1517$ and the value of table $=0.161$ because $\mathrm{L}_{0}<\mathrm{L}_{\text {tabel, }}$, so the results of data in the control class have contribution normal. On the other hand, the testing of homogeneities, using the criteria of testing $\mathrm{H}_{0}$ is accepted if $F_{\text {hitung }}<\mathrm{F}_{\text {tabel }}$ and $\mathrm{H}_{0}$ is refused if $F_{\text {hitung }}>F_{\text {tabel. }}$ : from the result of testing homogeneities, it can be gotten $F_{\text {hitung }} 1.43<F_{\text {tabel }} 1.85$, it meant that the data are homogeny. Testing of hypothesis with the value $\mathrm{t}$ which are gotten from the accounting 15.17 and $t_{\text {tabel }}=1.67$. According to the criteria of hypothesis testing, $\mathrm{H}_{0}$ is refused if $t_{\text {hitung }}>t_{\text {tabel. }}$. Based on the result, it can be concluded that $\mathrm{H}_{0}$ is refused and 
$\mathrm{H}_{\mathrm{i}}$ is accepted in the significant level $\alpha=0,05$.

Based on the statement above, it can be concluded that the result of research said that there is good effect clustering technique in improving the third students' ability in writing description text.

\section{REFERENCES}

Arikunto, Suharsimi. 2016. Prosedur Penelitian Suatu Pendekatan Prakti. Jakarta. Rineka Cipta.

Axelord, Rise B and Charles R. Cooper. 2005. The St. Martin's Guide to Writing, New York: St.Martin's Press.

Barbara, fine Clouse. 2004. The Student Write. McGraw-Hill Companies, Inc.

Baroudy, I. 2008. "A Procedural Approach to Process Theory of Writing: Prewriting Techniques". The International Journal of Language Society and Culture, 24

Betty Mattix. 2003 Reasoning and Writing Well; A Rhetoric, Research Guide, Reader, and Handbook-3rd ed,. New York: McGraw-Hill Companies, Inc.,.

Brown, H. Douglas. 2005. Teaching by Principles: An Interactive Approach to Language Pedagogy (Second Edition). New York: Addison Wesley Longman, Inc.

Dietsch, Betty Mattix. 2003. Reasoning and Writing Well, New York: MacGraw Hill.

Folit, R. 2009. Gabriele Lusser Rico Talks about the Benefits of Journaling.[Online]. Available at: http://blog.lifejournal.com/2009/06/12/gabriele-lusser-rico-talks-aboutthe-benefits-of-journaling/[Oktober 7, 2017

Fraenkel, J.R., and Wallen N. E. 2006. How to Design and Evaluate Research in Education (Sixth edition). New York: McGraw-Hill

Gall, Meredith D, Joyce P.Dall, and Walter R. Borg. 2003. Educational research an introduction. New York: pearson Education, Inc.

Gerot, Linda and Peter Wignell. 2002. Making Sense of Functional Grammar (the fourth edition). Sydney: Antipadean educational Enterprises.

Jack C. Richards and Theodore S.Rodgers. 2000. Approaches and methods in Language Teaching. New York: Cambridge University Press. 
Jerry G. Gebhard. 2006. Teaching English as a Foreign or second Language (2nd Edition), United State of America: The University of Michigan.

Limbong, Kerlinger. 2003. Suggested Material for Teaching Writing to SMEA Students. Thesis S1 unpublished. Semarang: FPBS IKIP Semarang.

Mark, Anderson and Kathy Anderson. 2010. Text Type in English 3. Australia: MacMillan.

Meyers, Alan. 2005. Gateways to Academic Writing: Effective Sentences Paragraph and Essays. New York: Education Pearson.

Puspito, Fera. 2013. The Influence Of Clustering Technique Toward Writing Skill To The Third Class Of Hearing Impairment Student In SDLB-B Karya Mulia 1 Surabaya (thesis). Surabaya: Program S1 Surabaya State University.

Rico, G.L.2000. Writing the Natural Way. [Online]. Available at: http://www.amazon.com/reader/0874779618?_encoding=UTF8\&page=2 8\#reader_0874779618 [September, 04,2017]

Sudjana, Nana.2002. Penilaian Hasil Proses Belajar Mengajar. Bandung: PT. Remaja Rosdikarya.

Suheni, Afrilia. 2011. The Use of Clustering Technique to Improve Students' Ability in Writing Analytical Expositions for Senior High School <An Experimental Research at the Students of the State Senior High School 1 Weru Sukoharjo of the Eleventh Year in the academic year 2010/2011> (skripsi). Semarang : Program S1 Universitas Negeri Semarang 